\title{
El Tema del Amor Imposible en María de Jorge Isaacs
}

M

ARÍa es el ejemplo literario de la concepción romántica del amor imposible. Presenta el mismo tema que se desarrolla en Poul et Virginie de Bernardine de Saint Pierre y Atala de Chateaubriand. Cuando Paul cree reunirse finalmente con Virginie, la pierde en el naufragio; cuando Chactas gana el corazón de Atala, la precipita al suicidio. Es la ironía romántica. En torno a los amantes la fatalidad teje progresivamente una red invisible que los empuja a la muerte, obstáculo sobrehumano e invencible.

En los amores de María y Efraín, la muerte es también el obstáculo insuperable. Los jóvenes han ido venciendo paulatinamente las barreras humanas que se oponían a su unión: la oposición de los padres, el presunto rival Carlos, la distancia y la separación física, y aun el tiempo.

El amor de Efraín, aunque derrotado por la muerte, sobrevive al tiempo. Los largos años transcurridos desde la muerte de la amada no han mitigado su emoción. Escribe el protagonista, ya viejo, tendiendo su mirada al pasado inmóvil, inmutable en su recuerdo:

...porque no he vuelto a oírlas [las palabras

de María], porque pronunciadas por otros labios

no son las mismas, y escritas en estas

páginas aparecían sin sentido. Pertencen a

otro idioma, del cual hace muchos años no viene

a mi memoria ni una frase. ${ }^{1}$

De igual manera Chactas, fiel a la memoria de Atala, la llora y evoca en su vejez:

1 Jorge Isaacs, María (New York, 1922). Las citas a la obra se referirán a esta edición, con las páginas entre paréntesis dentro del texto del artículo. 


\author{
Oh! Première promenade de l'amour \\ il faut que votre souvenir soit \\ bien puissant, puisque, après tant \\ d'années d'infortune vous remuez \\ encore le coeur du vieux Chactas. ${ }^{2}$
}

Efraín transcurre el resto de su vida lejos de los lares familiares, alejado del paterno hogar. Extraños ocupan los lares amados. Su existencia, pues, como la del típico héroe romántico, es errante y solitaria. EI "pathos" de su vida vagabunda se expresa en la frase siguiente: ". . había visitado yo todos los sitios que me eran queridos, y que no debía volver a ver..." (p. 158). Es el mismo sentimiento doloroso que deja traslucir Chactas cuando exclama:

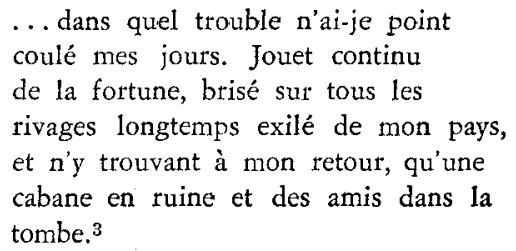

María y Efraín, héroes románticos del tipo concebido por Rousseau, Saint Pierre y Chateaubriand, leen emocionados la historia desgraciada de Atala. Efraín recita en voz alta el párrafo que profetiza el sino de María:

\footnotetext{
Duerme en paz en extranjera tierra, joven desventurada, en recompensa de tu amor, de tu destierro y de tu muerte, quedas abandonada hasta del mismo Chactas (p. 34).
}

Efectivamente, María, como Atala, dormirá en tierra extranjera; Efraín, como Chactas, parte lejos de donde yacen los restos mortales de la amada muerta en la flor de la vida. Antes va a abrazar la cruz de su sepulcro y a darle "el último adiós" (p. 160). Luego parte a galope por la llanura solitaria, cuyo vasto horizonte ennegrece la noche.

La psicología de María y Efraín es superficial. El retrato de la heroína, estereotipado. María es toda bondad, dulzura, sonriente, amable, pura. Sus rasgos característicos son convencionales. Su belleza física es idealmente convencional: tez alabastrina, grandes ojos de anchos párpa-

2 François-René de Chateaubriand, Atala-René (París, 1960), p. 72.

3 Ibid., p. 100. 
dos orlados de espesas pestañas y expresión angelical. Los rasgos sensuales se cancelan cuidadosamente, aunque tres veces se alude a sus bellos brazo; dos, a su terso cuello, y una a su pecho. María es tan pundorosa que una mañana que el amado la sorprende en el jardín con los pies desnudos, se arrodilla para cubrírselos con el vestido. Efraín la califica de "divina" (p. 56), poseedora de ese "don del cielo que diviniza a las mujeres" (p. 32). Como Anderson Imbert observa, María es la mujer-ángel creación del romanticismo.

Con el romanticismo la mujer se convierte en un objeto exaltado de los poetas, alado, exquisito, casi sobrenatural. Es la "beauté celeste" de René, 5 la "Silphide" de las Memoires d'outre-tombe.

Efraín es joven, inteligente, de aspecto noble, poeta y amante, de sensibilidad superior al vulgo $y$, por tanto, condenado a la soledad y a la incomprensión. Indirectamente precipita el fin de la amada, ya condenada a una muerte prematura. Efraín posee, pues, los rasgos del héroe fatal:

...the romantic hero plays several roles.

$\mathrm{He}$ is a poet-prophet, man of sensibility,

psychopath, solitary, wanderer, criminal, rebel, seeker, prototype of the Messiah. $\mathrm{He}$ is the fatal man, the pale genius, the ostracized magus, the victim of fate. ${ }^{7}$

Efraín, como René y como Chactas, atrae la desgracia sobre sí y sobre los seres que ama.

Los protagonistas de María se mueven en un medio idílico, un universo encantado en el que todos son buenos, nobles y generosos. La servidumbre de negros representa la sociedad no corrompida por la civilización: el paraíso del indio salvaje de tan remota tradición literaria. Las numerosas referencias a la simplicidad de vida de los amantes es, como explica Chateaubriand, "cette simplicité qui fait le bonheur". ${ }^{8}$

La naturaleza, en este microcosmos encantado, refleja el estado anímico de los personajes, $y$ es sensible a sus tristezas y alegrías. La compenetración entre la cosas, los animales y los hombres es profunda. Así, p. 191

4 Angel Valbuena Prat, Historia de la Literatura española (Barcelona, 1950),

5 Atala-René, p. 150. p. 114.

6 François-René de Chateaubriand, Memoires d'outre-tombe (Paris, 1889),

7 George Ross Ridge, The Hero in French Romantic Literature (Georgia, 1959), p. 11.

8 Aiala-René, p. 143. 
Efraín, ante la muerte de la heroína, se siente como el ave empujada por el huracán y se sumerge a galope en la noche que se cierne sobre la llanura.

La tempestad, la bonanza, los anchos horizontes y los escenarios majestuosos sirven de marco a la pasión desmensurada que se evidencia con grandes gestos teatrales. La melancolia, la nostalgia, el sentimiento religioso son otros tantos elementos que aderezan la gran pasión romántica: el amor imposible.

Northwestern University

María J. Embeita 